\title{
The Potential Of Open Education Resources To Boost High School Education In South Africa's Kwazulu-Natal Province
}

Alex van der Merwe, Durban University of Technology, South Africa

\begin{abstract}
Many South African high schools are under-performing with poor pass rates, particularly in mathematics and physical science. Although the country's state of education would seem to be dire, pockets of excellence thrive in many local schools. Given this available expertise, a free and open education resource (OER) base adapted to local conditions and the necessary will, it may be possible to grow vibrant local open education communities and thus promote more equitable access to better quality education. This descriptive study sought to examine the attitudes of a sample of South African high school teachers towards OERs with the aim of gauging their willingness and capacity to use and/or develop these materials within an open economic model/framework.

The study established that, in spite of respondents' recognition of the potential advantages of OERs, and even some significant reported use of these instructional tools, there appear to be serious doubts as to the level of institutional support for such open education initiatives. This is unfortunate since teachers appear to be sympathetic to the philosophy of open education and are prepared to donate regular time and effort to the business of developing these resources. The study concludes that policy, at both school and departmental levels, should be sharply realigned to embrace and actively promote the development and more widespread use of open resources. Only then is the economics of open education likely to be unleashed on a transformative scale.
\end{abstract}

Keywords: Education; Open Education; Open Education Resources

\section{INTRODUCTION}

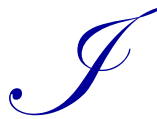

n spite of a significant annual national budget allocation for education, South African literacy and numeracy rank near the bottom of every international marker for these basic life skills (SaundersonMeyer, 2011). Bloch (2009) confirms that, despite significant resources, only about thirty percent of children in grades 3 to 6 at South African schools perform at the level required for literacy or numeracy. These educational outcomes, he notes, are among the worst in Africa.

Against this background, the core research problem that this study is concerned with is how open educational resources (OERs) might be employed in a spirit of community engagement in South African high schools to improve, not only the quality of education, but also wider and more equitable access to it. As such, it explores the terrain upon which an alternative business/economic model might powerfully leverage the public's good nature of knowledge. An education business/economic model, which recognizes that knowledge can be improved when it is shared openly, is perhaps the sort of revolutionary approach that is needed to produce more efficient and healthy educational outcomes. The extent to which this can be achieved depends significantly on the attitudes, willingness and capacity of expert teachers currently working in the country's better resourced schools. It is this cadre that must decide whether, and how much, it wants to share in terms of skills, experience and resources with under-qualified, poorly equipped and inexperienced teachers in the school system and even with pupils who must teach themselves and each other because of a shortage of qualified and experienced teachers. 
This exploratory study thus explores the attitudes of high school teachers in South Africa's KwaZulu-Natal province to open education initiatives and open education resources. A culture of community sharing in the spirit of open education, embraced and fostered by a critical mass of teachers, could potentially serve as a keystone in the country's high school system. As such, this study is a response to Van der Berg et al.'s (2011) 6-point vision for improving quality in education. Specifically, it seeks to promote teaching capacity and strengthen relationships of accountability and support amongst stakeholders by gauging teachers' receptiveness to the philosophy of open education and open education resources.

\section{BACKGROUND}

\section{The Ugly Facts}

The fact that South Africa faces a crisis in its education system is evident from a cursory review of various performance measures. Of the 1,627,004 pupils who took the matric (grade 12) school leaving exams between 2009 and 2011, 54\% failed (Masondo, 2014). During the same period, 37.4\% of Grade 11 pupils failed as did 23.1\% of those in Grade 10. What makes these figures even more alarming is that they mask a very high incidence of repeat students in each grade. Thus, an average of $22.6 \%$ of pupils per year were repeating grade 10 in the period 20102012.

The average proportion of pupils repeating Grade 11 during the same period was only slightly lower, at 20\% (Masondo, 2014). The momentum that drives this spectacular scale of failure builds up through the lower grades. KwaZulu-Natal Grade 9 pupils scored an average of 12\% in mathematics in the 2012 annual National Assessments (Ngcobo and Biyela, 2012) and 37.7\% in their home languages.

The poor overall matric performance takes on sharper definition if one considers the average national results in key subjects as shown in Table 1:

Table 1: Average National Results In Key Subjects In The Matric Exams 2008-2010

\begin{tabular}{|c|c|c|c|}
\hline Subject & $\mathbf{2 0 1 0} \%$ & $\mathbf{2 0 0 9} \%$ & $\mathbf{2 0 0 8} \%$ \\
\hline Mathematics & 28.9 & 27.3 & 28.26 \\
\hline Life Sciences & 38 & 34.84 & 35.15 \\
\hline Geography & 34.8 & 35.07 & 35.80 \\
\hline Accounting & 33 & 32 & 33 \\
\hline Physical Science & 30.26 & 25.14 & \\
\hline Source: Ntsaluba and Rademeyer (2011)
\end{tabular}

This pattern of nightmare results continues into 2011 during which time one in six pupils scored less than $10 \%$ for Grade 12. Mathematics and more than half achieved less than 30\% for Physical Science (Pauw et al., 2012). Exam results in 2011 for selected subjects (shown in Table 2) confirm the general trend of very weak performance of South Africa's educational system. 
Table 2: Unadjusted Exam Results For Selected Subjects (2011)

\begin{tabular}{|c|c|c|c|}
\hline Subject & Number Of Candidates & Failed (\%) & Average Mark (\%) \\
\hline Mathematics & 224874 & 59.22 & 29.11 \\
\hline Physical Science & 180746 & 5.41 & 32.48 \\
\hline Economics & 133493 & 57.3 & 32.82 \\
\hline Accounting & 138109 & 51.1 & 33.75 \\
\hline Geography & 199271 & 39.26 & 34.9 \\
\hline Life Science & 265157 & 43.5 & 42.5 \\
\hline History & 85504 & 24.4 & \\
\hline Source: Pauw et al., 2012
\end{tabular}

If the failure rate does not seem to square with the average mark, the fact that a "pass" ranges between 30$40 \%$, depending on the subject, will be of small comfort. However one looks at it, these results paint a bleak picture of South Africa's education system.

Performance problems experienced at the high school level are likely to have their roots in the primary and foundation phases of schooling. A recent report states that the majority of poor pupils start falling behind required literacy and numeracy levels in their first year and by the end of the foundation phase in Grade 3, many have dropped out and consequently fail to master the curriculum in later years (Ashton, 2013). Ashton notes that this state of affairs has been advanced as the primary reason why $50 \%$ of children drop out of school before they reach matric. Thus, for example, the 2012 matric class started Grade 1 in 2001 as a group of 1,1520,637 pupils, but only 551,837 took the National Senior Certificate school exit examinations.

Systemic poor performance at the primary and, subsequently, high school levels is likely to domino through to higher education. In 2012, it was estimated that of 100 children that started school, 40 took the matric examinations, 28 passed, and four enrolled at universities, with only one graduating (Jones, 2012). Besides the consistently poor graduation rates of around $25 \%$ of original enrollments, just $35 \%$ of the total intake, and $48 \%$ of contact students, graduate within five years (Macfarlane, 2013). Macfarlane notes that, due to disparities in access and success, less than 5\% of African and Coloured youth currently succeed in any form of higher education. He notes that poor academic preparation at school level has been identified as the "the dominant learning-related reason" for weak university performance.

\section{Where To Apportion Blame?}

The generally poor performance of South Africa's education system does not make sense if one considers that education traditionally receives the lion's share of national budget allocations. Thus in the 2012-2013 financial year, for instance, R232.5 billion of the country's R1.06 trillion national budget was allocated to education (Anon. 2013). This, more or less, has been the trend since South Africa's transition to democracy in 1994. Thus a lack of resources cannot be the sole reason for the parlous state of the country's education system. Indeed Taylor cites evidence to suggest that there is no deterministic relationship between resource availability and performance (Taylor, 2008).

The poor state of education in South Africa has been attributed to a low quality of teaching and learning (Taylor, 2008; Van der Berg et al., 2011; Masondo, 2014), absentee teachers, poor management of many schools, and a shortage of suitably qualified teachers (Mngoma, 2011; Macfarlane and Chaykowski, 2011; Gernetsky, 2012; Ngcobo, 2013). Christiansen (2011) notes, however, that factors related to the teacher predict only $30 \%$ of the difference in pupils' performances. The remaining $70 \%$ is accounted for by individual pupil characteristics, socioeconomic factors, peers, and the school.

Bloch (2009) concurs that South Africa's education crisis is, in fact, a complex and potent mix of problems. These include not only poor management and administration but also a lack of support for teachers and learners in a society challenged by conditions of poverty and inequality. Thus, issues that complicate the business of education locally include resident gangs, language barriers, poor nutrition, ill health, a lack of transport, overcrowding, a deficiency of laboratories, and staff rooms and libraries in poorer schools. Teacher union resistance to actions aimed at addressing the educational system's deficiencies is evidently a further confounding factor that inhibits meaningful 
reform (Anon, 2011; Saunderson-Meyer, 2011). This gamut of ailments might, not unreasonably, be expected to impact negatively on the quality of education.

\section{The Focus On Education Quality}

Following several decades of efforts to promote universal access to education globally, the focus within educational development work has been shifting towards improving the quality of schooling (Department of Basic Education, 2013). Van der Berg et al. (2011) note that the pattern of public spending on education in South Africa has changed from being highly unequal on the basis of race under Apartheid to being well targeted towards poor children. In spite of this positive development, an enduring legacy from the past is the low quality of education within the historically disadvantaged parts of the school system. Taylor (2008) agrees that the South African school sector can be characterised as a high cost, high participation, low quality system.

According to van der Berg et al. (2011), the rate of attainment of levels of education up until about 11 years is relatively high in South Africa compared to other middle-income countries. However, beyond 12 years of education, South Africa's attainment rate ranks amongst the lowest of these countries. They conclude that, as far as access to education is concerned, South Africa appears to be doing well throughout most of the primary and secondary phases but poorly thereafter. Van der Berg et al. caution that high rates of grade progression, despite a generally low quality of schooling in the primary and early secondary phases, ultimately results in substantial dropout prior to the standardised matric examination, failure to pass matric, and failure to achieve a university endorsement. They propose that the reality of greater access to education at the school level masks the deeper problem of its quality.

The problems of poor quality education are acknowledged to be significantly rooted in the primary and secondary schooling phases (Department of Basic Education, 2013). Van der Berg et al. (2011) observe that, according to a Southern and East African Consortium for Monitoring Education Quality (SACMEQ) survey in 2007 of Grade 6 mathematics and reading, South Africa performed worse than most African countries that participated in the study. They lament the finding that a large proportion of Grade 6 learners had not mastered even the most basic reading and numeracy skills. Of the 15 education systems that participated in the survey, South Africa was found to have the third highest proportion of functionally illiterate learners (27\%) and the fifth highest proportion of functionally innumerate learners (40\%).

\section{Where To Grasp The Nettle?}

Where does one begin to repair a dysfunctional education system whose state is a consequence of seemingly myriad factors? The McKinsey (Anon, 2007) Report proposes the following three guiding principles for achieving improvement in outcomes:

- $\quad$ The quality of an education system cannot exceed the quality of its teachers.

- $\quad$ The only way to improve outcomes is to improve instruction.

- $\quad$ Achieving universally high outcomes is only possible by putting in place mechanisms to ensure that schools deliver high-quality instruction to every child.

However, given the education system's current capacity limitations and efficiency problems, how does one practically improve the quality of teachers and instruction? In the face of persistent resource constraints, what mechanisms might potentially deliver high quality instruction on a scalable and sustainable basis?

\section{Enter Communities Of Practice And Open Education Resources}

The reality is that education in South Africa will have to be restored to health without the benefit of additional massive infusions of funds and manpower. However, progress towards this end could be made by reorganizing teacher training and development so that more of it takes place within communities of practice that are committed to open educational practices (OEP). Hoosen (2009) notes that the term "Community of Practice" (CoP) 
has been used in different ways and usually refers to informal networks that support people to develop shared meaning and engage in knowledge building.

Ehlers and Conole (2010) observe that OEPs have been defined as a set of activities and efforts that support the creation, use and repurposing of open educational resources (OERs). The "term open educational resources" (OER) was first adopted at the 2002 UNESCO Forum on the Impact of Open Courseware for Higher Education in Developing Countries at which time, according to Friesen (2009), it referred to the open provision of educational resources, enabled by information and communication technologies, for consultation use and adaptation by a community of users for noncommercial purposes.

\section{The Promise}

The prospect of teacher communities embracing and sharing OERs suggests an appealing synergy. Thus, efforts to develop and share open educational resources, whether online or in face-to-face settings, naturally lend themselves to collaboration, and so it is conceivable that OER sharing and development may give rise to, and sustain, vibrant teacher communities of practice. This virtuous cycle of open educational practices producing communities of practice offers a potentially powerful regenerative force within South African education.

Evidence cited in the literature supports the proposition that communities of practice built around open educational practices and open educational resources is a viable approach to teacher professional development. Duncan-Howell (2007) finds that online communities of practice are a valuable source of continuous professional development for teachers. She notes that CoPs offer support to teachers who are required to accommodate frequent changes and constantly have to acquire new skills and knowledge. She concurs that a notable strength of this method of professional development is its ability to be self-sustaining and regenerative. McKay (2007), in his study of a high school Biology Teachers' Network in a South African setting, finds that it exhibits all the elements of a distributed Community of Practice. He notes that legitimate peripheral participation, negotiation of meaning through participation and reification of the shared discourse are evident in the sharing of information, collective problem solving and interactions.

Hoosen (2009) reports the mixed experiences of two South African case studies of teacher/instructor CoPs that functioned well in face-to-face workshop-style settings but could not be sustained beyond these physical meetings, even with ICT and internet capacity. Some of the problems cited by members of these CoPs include a lack of time to engage in OER creation, a lack of time to familiarise oneself with ICTs, technical problems experienced with ICTs, poor/no internet access, a focus on production as opposed to collaboration, and confusion over copyright issues.

It seems intuitive that the vitality of teacher communities of practice depends significantly on their perceptions of the benefits of OERs and open educational practices, which consideration is the focus of this paper. In the minds of instructors, these will be traded off against the perceived challenges that these resources and practices present and are discussed in a separate paper.

\section{Two Sides To A Coin: Potential And Challenges}

Anticipated benefits of open educational resources, according to Geser (2007), include:

- $\quad$ The creation of networks for the production and sharing of educational materials based on a strong emphasis of re-usability. This benefit would include the prospect of leveraging the educational quality of content through quality control, feedback and improvements within content alliances, communities and networks who share content.

- Boosting the pool of resources (content and tools) for redesigning curricula and improving teaching and learning practices without having to worry about copyright issues

- Improved returns on public funds invested in education through greater cost-effectiveness when reusing resources (e.g. sharing development costs among institutions or professional communities) 
Furthermore, open education may foster lifelong learning and social inclusion through easy access to resources that might otherwise not be accessible.

In spite of their considerable potential, the promise of open education and OERs has often not translated into concrete and tangible results (Kanwar et al., 2010). A significant reason for this circumstance is the issue of sustainability. Most OER initiatives are introduced and sustained by donor funding and if this is withdrawn, projects typically fail. An example of this tendency is the discontinuation of Utah State University's Open Courseware Movement which, in spite of its excellence, was aborted in 2009 due to lack of funding (Kanwar et al., 2010). Other challenges include uncertainty regarding the issues of quality assurance and licensing (Yuan et al, 2008; Hodgkinson-Williams, 2010), a lack of broadband and other technical innovations, interoperability issues, and a lack of time to produce shareable materials. A deficiency of technical skills, unwillingness to share or give away intellectual property, a reluctance to use resources developed by someone else, and a lack of awareness of copyright have also been cited as factors that may slow the uptake of OERs.

It has been suggested that the attitudes of instructors towards open education may profoundly affect its pedagogic value in terms of producing superior learning relative to traditional 'closed' modes of education (Elias and Elias, 2001). The descriptive analysis that follows explores KZN high school teachers' propensity to use, share, and develop OERs. The viability of local teacher CoPs as a potential mechanism to boost the quality of teaching and learning rests significantly on its findings.

\section{METHOD}

This case study was based on an online survey of KZN public and private high schools in the Midlands (Pietermaritzburg) and Pinetown and Umlazi areas of Durban. The study employs descriptive analysis within an essentially qualitative research design.

\section{The Survey Instrument}

The electronic questionnaire comprised a general section in which some biographical information was elicited and also a section dealing with open educational resources in the classroom. The entire questionnaire comprises 32 items that are a mix of written, dichotomous/multiple choice and five-point Likert scale questions.

Following piloting and some subsequent revision, the questionnaire was administered in the first half of 2013 with a follow-up invitation to teachers to participate in the survey during the second half of the year. The questionnaire did not force responses and some respondents, accordingly, may have chosen not to disclose certain information.

\section{Data Cleansing}

Unfortunately, the data collection process was plagued by significant unit and item non response. Perhaps this is to be expected in a survey of this nature where respondents' knowledge and experience of open education resources and copyright issues may be tentative. The relatively high rate of questionnaire completion (95\%) in the face of significant non response on some items suggests that this is probably the case. It is likely, thus, that the incidence of item non-response, especially in respect of attitudes towards open education resources (the Likert scale items), suggests uncertainty with respect to these items rather than indicating potential sample bias. Notwithstanding this, cases with extensive item non response were removed from the sample, including those with missing demographic data.

The incidence of item non-response was most notable with regard to the Likert scale items and ranged between $8 \%$ and $26 \%$. Little's MCAR test $(\mathrm{p}=0.462)$ suggests, however, that the missing data, with respect to the final sample, are randomly distributed across all observations and that the incidence of this missingness is therefore unlikely to be linked to respondents' characteristics. Accordingly, all the sample cases were analysed using list-wise deletion to exclude those with missing data. 
The dichotomous and rating scale items, for the questionnaire as a whole, appeared to have good internal measurement consistency (Cronbach's Apha $=0.743>0.7$ ). The rating scale items, in particular, are all indicated as having a high internal consistency in terms of gauging respondents' attitudes towards various aspects of open education resources $($ Cronbach's Alpha $=0.871>0.7)$.

\section{Population Characteristics}

Beyond working at public versus private/independent schools, not much is known about the population of teachers in these schools or their demographic characteristics. Table 3 reflects the breakdown of the population of high schools in the Pietermaritzburg and Durban areas.

Table 3: Distribution Of High Schools In The Study Area

\begin{tabular}{|c|c|c|}
\hline Area & Number & Rounded To Nearest Percent \\
\hline Pietermaritzburg & 60 & 59 \\
\hline Durban & 42 & 41 \\
\hline
\end{tabular}
schools.

Roughly $74 \%$ of these schools are public or state-funded schools while the balance consists of private

\section{Sample Characteristics}

Table 4 reflects the frequency distribution of responses received from KZN high schools.

Table 4: Frequency Distribution Of Responses

\begin{tabular}{|c|c|c|} 
Table 4: Frequency Distribution Of Responses \\
\begin{tabular}{|c|c|c|}
\hline Area & Number & Percent \\
\hline Pietermaritzburg & 61 & 39 \\
\hline Durban & 39 & 39 \\
\hline
\end{tabular}
\end{tabular}

The sample comprised more females $(60 \%)$ than males. The average age of respondents was 44.65 years, with the median age being 45 years. The average number of years of service of respondents was 18.69 , with the median being 18 years. The proportion of the sample that had masters degrees is $15 \%$ and $41 \%$ were in possession of a National Higher Diploma/Bachelor of Technology/Honours degree. The remaining respondents were qualified at national diploma/basic degree level $(37 \%)$ or had other qualifications (7\%). A comparison of the sample proportions of Pietermaritzburg and Durban respondents, with the population proportions of Durban and Pietermaritzburg schools, indicates that the former is closely representative of the latter. Furthermore, the proportions of respondents from private (58\%) and public (42\%) high schools, while not ideal, suggest an acceptable approximation of that occurring in the population.

\section{ANALYSIS}

\section{In What Circumstances Are Teachers Employing Open Education Resources?}

The open educational resource experiences of teachers should be appreciated in the context of their circumstances. Thus, with respect to their core function of teaching, the average number of students per class taught by respondents was 24 and each respondent was involved in teaching at least one or more levels, ranging from grades 8 to 12 as well as post grade 12/matric level. Asked to rate the socio-economic background of their pupils, the majority of respondents (95\%) indicated that they were generally in the middle-to-upper income bracket. This is significant in that one would expect pupils from such a background to be attending relatively well resourced schools. It is schools such as these that are likely to form the bedrock on which open education initiatives must be built if they are to be self-sustaining.

Asked whether they use any open educational content in their teaching approach, $68 \%$ of respondents confirmed that they do. It is noteworthy that $16 \%$ of the respondents confirmed that they source materials online but were not sure about the copyright status pertaining to these resources. Figure 1 gives a breakdown of the range of subjects taught by the teachers who were surveyed and Figure 2 reflects the various resources employed by teachers. 


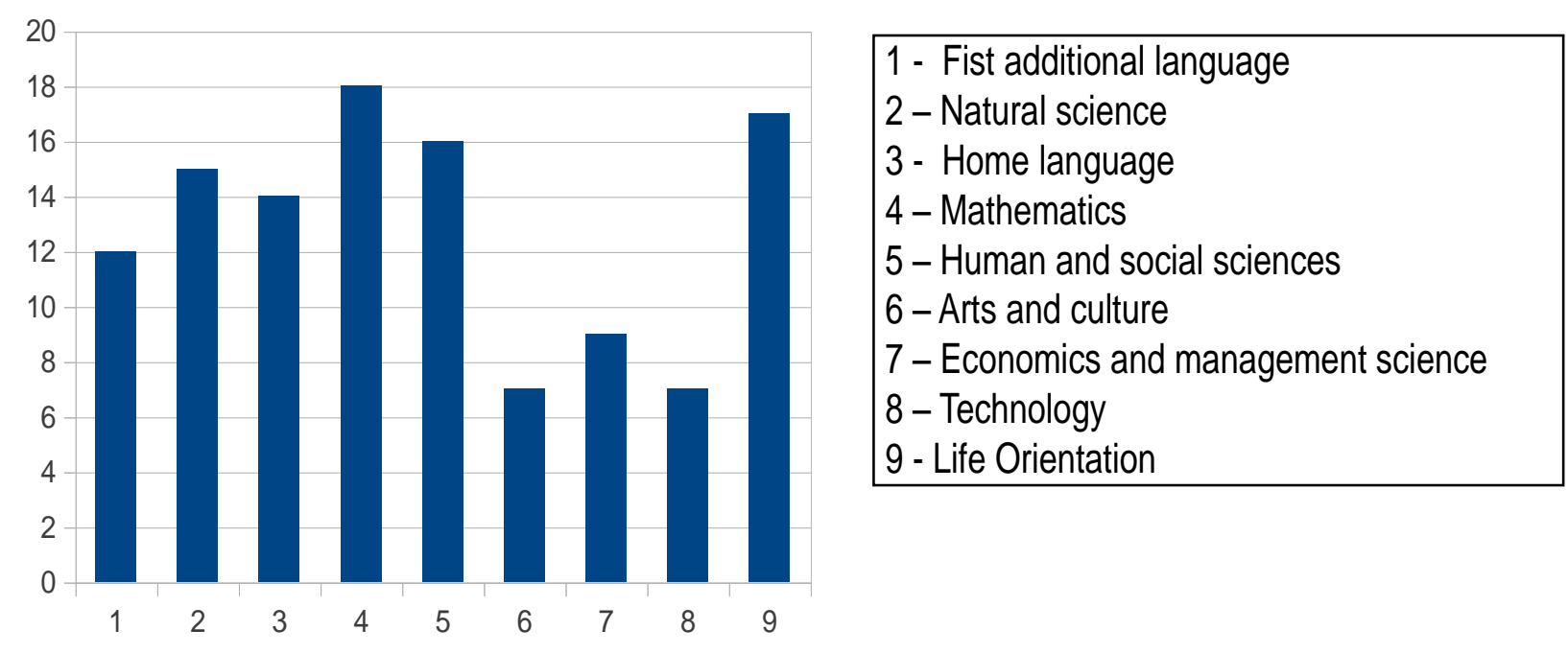

Figure 1: Subjects Taught By Percent Of Respondents

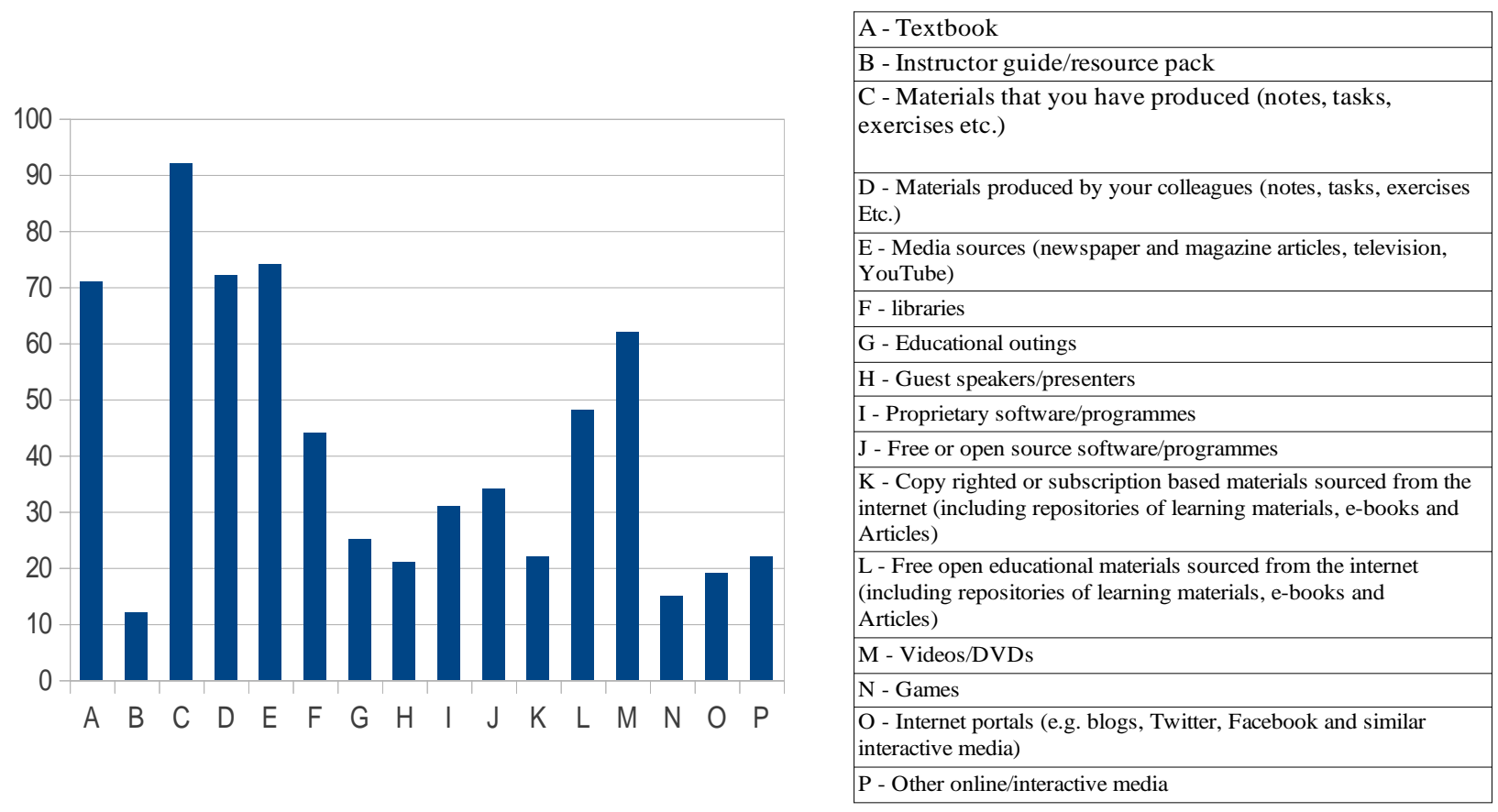

Figure 2: Resources Employed By Percent Of Respondents

According to Figure 2, although online open educational resources were employed by $48 \%$ of respondents, the most popular materials are those produced by teachers themselves (92\%), media sources at $74 \%$ (newspapers/magazine articles, YouTube etc.), resources developed by colleagues (72\%), and prescribed texts $(71 \%)$. The fact that the majority of respondents rely on shared materials (i.e., produced by colleagues) as one of a few preferred teaching resources holds promise in terms of building sharing networks beyond specific departments and individual schools. 
Respondents indicated that, on average, about $30 \%$ of their instructional materials comprised open educational resources as defined in this study. Figure 3 describes the nature of these various resources. Notes (55\%), tasks/assignments (43\%), exercises/quizzes (56\%), other free online content (40\%) and Videos/DVDs (56\%) were the most popular materials.

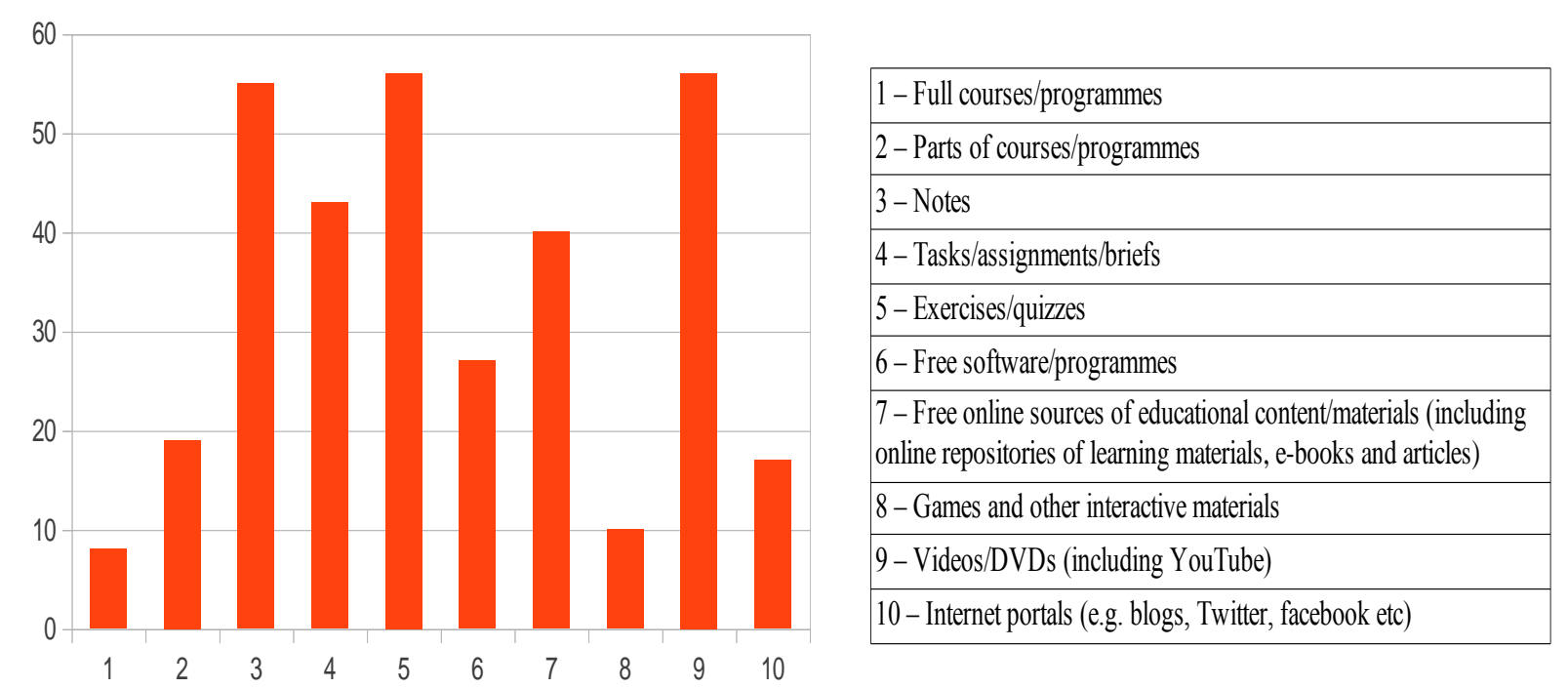

Figure 3: Types Of Open Educational Resources Employed By Percent Of Respondents

\section{Teacher Perceptions Of Open Education Resources And Attitudes Towards Openness}

\section{Perceptions Of Quality}

Table 5 offers some insight into the opinions teachers had of the quality of open educational resources in their respective disciplines. While $68 \%$ of respondents considered the quality of these materials to be at least reasonable, $16 \%$ were uncertain of the quality and $15 \%$ thought it was at least below par. However, the fact that close to $70 \%$ of the teachers surveyed felt that free open educational resources are generally valuable suggests that they can play a potentially significant role in educational outreach and in boosting the education system's resource base.

Table 5: Respondents' Perceived Quality Of Oers

\begin{tabular}{|c|c|}
\hline Opinion Of Quality & Percent \\
\hline Generally good & 23 \\
\hline Reasonable & 46 \\
\hline Uncertain & 16 \\
\hline Below par (relative to copyright-protected) materials & 10 \\
\hline Poor & 5 \\
\hline
\end{tabular}

\section{Teacher ICT Proficiency}

Since OERs are primarily distributed and accessed online, it is important to gauge teachers' level of comfort with respect to using ICTs (information and communication technologies) as well as their confidence in using these tools. Respondents were invited to self-rate their level of comfort with ICTs on a scale of 0-10, with 0 indicating zero comfort and $10=100 \%$ comfort. The mean level of comfort indicated was 8 . As one might expect, the mean proficiency score corresponds closely with the mean comfort score (mean proficiency score $=8.5$ ). These findings suggest that KZN high school teachers appear to be sufficiently qualified to at least comfortably and proficiently access the bulk of OERs online. 


\section{Motivating Factors For Teachers To Become Involved In Open Education Initiatives}

The survey evidence suggests that teachers in some of KZN's best resourced public and private schools are using open education resources and that they consider the quality of these resources to be at least reasonable. Furthermore, teachers appear to be sufficiently skilled to access the bulk of these educational materials online. In addition, there appears to be a significant degree of sharing of resources between teachers/colleagues at least within schools and departments. This suggests that there exists a foundation of sorts on which to build open education communities and initiatives. The question is whether the current collaboration and sharing within particular schools and departments can be leveraged and scaled up to include other schools across the province. To answer this question, one would need to know not only what motivates teachers to use open education resources but also what would inspire them to collaborate in the development of these materials and share them on a bigger stage.

Respondents were invited to rate the extent to which they agreed with stated goals that could be associated with using and/or developing open educational resources. Responses were scored using a 5-point Likert scale where $1=$ "very important" and $5=$ "unimportant". Table 6 displays the responses of teachers who felt that the stated goals were at least important considerations with respect to engaging with open educational resources.

Table 6: Respondents' Goals In Terms Of Engaging With Open Education Resources

\begin{tabular}{|l|c|}
\hline \multicolumn{1}{|c|}{ Goal (Or Reason) } & $\begin{array}{c}\text { Percent } \\
\text { (Rounded To Nearest Percent) }\end{array}$ \\
\hline 1. Gain access to the best possible resources & 84 \\
\hline 2. Promote educational research as a publicly open activity & 70 \\
\hline 3. Bring down tuition costs for pupils & 80 \\
\hline 4. Reduce instructional costs for the school & 70 \\
\hline 5. Outreach to pupils in disadvantaged schools and communities & 84 \\
\hline 6. Contribute to teacher upgrading in rural and outlying poorly resourced schools & 84 \\
\hline 7. Become independent of commercial educational vendors (e.g. books and software) & 58 \\
\hline
\end{tabular}

Developing more suitable/flexible materials (88\%), gaining access to the best possible resources $(84 \%)$, and outreach to teachers and pupils in disadvantaged schools and communities (84\%) were the most important goals expressed by respondents.

A majority of respondents $(60 \%)$ indicated that they definitely would engage more with open education resources if dedicated technical support was on hand and a further $27 \%$ stated that they probably would. Respondents also indicated that they would be prepared to devote an average of 10 hours per month to developing open education materials. On the face of it, these are encouraging insights.

\section{Clearing The Way For Open Education}

It would appear, thus, that the necessary elements to start seeding and growing open education communities of practice are in place. The question is how to kick start the process and also ensure that these communities become self-sustaining.

In spite of the seemingly good prospects for open education projects, significant obstacles to these types of initiatives have been identified and will need to be addressed. Thus, for example, 29\% of respondents felt that they do not enjoy the support of school management in terms of more engagement with open education resources and practices and a further $25 \%$ were uncertain about the level of support of management in this regard. At the level of national/provincial education policy, $39 \%$ of respondents indicated that they do not have the support of the Department of Education, as far as involvement in open educational practices is concerned, and $28 \%$ stated that they could not be certain of such support. This is not good enough for open education to achieve its full potential. Policy, at both school and departmental levels, should be aggressively realigned to embrace and actively promote the development and more widespread use of open resources in no uncertain terms. This will help clear the way for teacher communities to spring up around collaborative projects such as OER development. 
The issue of incentives for teachers to collaborate in the development and sharing of resources must be considered in order to maintain their interest and commitment to such projects given the considerable demands on their time. In addition, the important consideration of how best to facilitate easier collaboration and sharing between teachers also deserves close attention. An open online infrastructure with superior functionality to email is required to establish, consolidate, and sustain teacher communities of practice that may grow out of easy file sharing, online discussions, forums, blogs, and online collaborative workshops/projects. South Africa's Western Cape Department of Education currently employs the Moodle system for exactly this purpose (Aghardien, 2010).

Finally, teachers' and schools' attitudes to their intellectual property and to the philosophy of open licensing will invariably have an impact on the success of open education initiatives and the longevity of open education teacher communities of practice. Teachers need a better understanding of the concepts of intellectual property, copyright, and open licensing. A better working knowledge of the different legal frameworks governing intellectual property should serve to reduce teachers' fears and inhibitions in terms of sourcing, adapting and distributing the work, not only of other authors, but also their own original creations.

\section{LIMITATIONS OF THE STUDY}

Due to a poor survey response rate and a consequently small sample size, the findings of this study cannot be generalised, with confidence, beyond the sample schools. Future similar studies could profitably analyse larger samples across more cases and also examine the attitudes of both teachers and pupils to OERs and open education. Future research should also attempt to identify barriers to OER engagement and open education initiatives, generally.

\section{CONCLUSION}

The poor state of education in South Africa has been blamed on low quality teaching and learning, primarily in the primary and secondary schooling phases. Among other factors, absentee teachers, poor management of schools, a lack of resources, and a shortage of skilled teachers have been implicated in this crisis. This state of affairs suggests a problematic business/economic model in terms of delivering quality education efficiently.

It is unlikely that significantly more resources will be channeled into education in order to improve the quality of teachers and instruction, given that it already enjoys the largest share of annual budgeted government expenditure and with only meagre returns to show for it. The reality is that there appears to be no more viable alternative than to tap the goodwill of the current core of expert and experienced teachers in the school system and to involve them more in teacher training and development. This might be achieved by fostering teacher communities of practice in the spirit of open education. These groups are likely to be based on, and sustained by, relationships that grow out of collaborating in the development and sharing of open educational resources.

The study established that teachers in some of KZN's best resourced schools are using open education resources and that the quality of these resources is considered to be at least reasonable. Furthermore, teachers appear to be sufficiently skilled to access the bulk of these materials online. There is also evidently a significant degree of sharing of resources between teachers and colleagues, at least within schools and departments, which fact holds promise for the prospect of building open education communities and initiatives across the province of KZN.

The success of open education initiatives depends crucially on the buy-in of teachers. It is important to know what motivates teachers to use open education resources and what would inspire them to develop and share these materials. The study found that the most important reasons teachers develop, use, and share these resources is to have access to more suitable/flexible materials, secure the best possible resources, and to engage in outreach to teachers and pupils in disadvantaged schools and communities. These shared goals, and the willingness of teachers to commit time and effort to developing open resources, suggest a real belief not only in the potential of these materials but also in the philosophy and spirit of open education. These findings suggest that an open education business/economic model - one based on the widespread promotion and employment of open education resources may find ready traction in South Africa's current educational setting, particularly in its KwaZulu-Natal province. 
For open education and such resources to play a meaningful role in addressing South Africa's education crisis, the support of teams or communities of expert teachers within its education system needs to be secured. This will mean gearing policy to create conducive and attractive open education environments. Thus, issues such as incentives for teachers, technical support, suitable open ICT platforms, and copyright and intellectual property concerns must be tackled. This would make for more solid ground on which teachers can base open educational practices.

\section{AUTHOR INFORMATION}

Alex van der Merwe lectures economics at the Durban University of Technology, Riverside campus.

Email: alexvdm@dut.ac.za.

\section{REFERENCES}

1. Aghardien. (2010). Western Cape Department of Education Moodle Project.

2. Anon. (2007). How the world's best-performing school systems come out on top (pp. 1-70). McKinsey \& Company. Retrieved from $\mathrm{http} / / \mathrm{www}$. google.com/url?sa=t\&rct=j\&q=\&esrc=s\&source=web\&cd=2\&ved=0CC4QFjAB\&url=http\%3 A\%2F\%2Fwww.smhc-cpre.org\%2Fwp-content\%2Fuploads\%2F2008\%2F07\%2Fhow-the-worlds-bestperforming-school-systems-come-out-on-top-sept072.pdf\&ei=JGTqUozQG5OIhQemyYHQBg\&usg=AFQjCNG1eD5CzDh6bbROzJyAYcH3SVwl0w\&sig 2=1i6mNMZuU0mERy_9z2qJvA\&bvm=bv.60444564,d.ZG4.

3. Anon. (2011, June 16). DA welcomes MEC's plan for extra classes for 555 schools. The Witness, p. 4.

4. Anon. (2013, February 27). Budget 2013: lion's share for education. South Africa.info. Retrieved from http://www.southafrica.info/about/education/budget13e.htm\#.UujAJ-KxU8o.

5. Ashton, M. (2013, May 23). Thumbs down to compulsory education. Finweek, pp. 8-11.

6. Bloch, G. (2009). Getting rid of OBE and other education fixes. New Agenda, 41-44.

7. $\quad$ Christiansen, I. M. (2011). Making maths matter. The Witness, p. 6.

8. Department of Basic Education. (2013). The Internal Efficiency of the School System A Report on selected aspects of access to education, grade repetition and learner performance (pp. 1-36). Pretoria: Department of Basic Education.

9. Duncan-Howell, J. (2007). Online Communities of Practice and their Role in the Professional Development of Teachers $(\mathrm{PhD})$. Queensland University of Technology, Brisbane. Retrieved from http://www.google.com/url?sa=t\&rct=j\&q=\&esrc=s\&source=web \&cd=1\&ved=0CDAQFjAA\&url=http\%3 A\%2F\%2Feprints.qut.edu.au\%2F16512\%2F1\%2FJennifer_Duncan-Howell_Thesis.pdf\&ei=te_vUotEcrIhAeu8IDYBw\&usg=AFQjCNEeXNY4BOYvSqQ1Qofn3zh1Zp20Zg\&sig2=a9rc_zHSOIjp8Q9BlbKx WQ\&bvm=bv.60444564,d.ZG4\&cad=rja.

10. Ehlers, U., \& Conole, G. C. (2010). Open Educational Practices: Unleashing the power of OER (pp. 1-10). Presented at the UNESCO Workshop on OER, Windhoek, Namibia. Retrieved from http://www.google.com/url?sa=t\&rct=j\&q=\&esrc=s\&source=web\&cd=1\&ved=0CCgQFjAA\&url=http $\% 3$ A $\% 2 F \% 2 F c d n . e f q u e l . o r g \% 2 F w p-c o n t e n t \% 2 F u p l o a d s \% 2 F 2012 \% 2 F 03 \% 2 F O E P$ Unleashing-the-power-ofOER.pdf\&ei=XovrUvKuHKS10AXgxoGYCw\&usg=AFQjCNGYYdUWBxVMRIDNCEtt2WoZ9myjcw\& sig2=LEA3XobYkbeZF25uQY9gDw\&bvm=bv.60444564,d.d2k.

11. Elias, S. F., \& Elias, J. W. (2001). Open Education and Teacher Attitudes toward Openness: The Impact on Students. Education, 99(2), 208-214.

12. Friesen, N. (2009). Open Educational Resources: New Possibilities for Change and Sustainability. The International Review of Research in Open and Distance Learning, 10(5), 1-7.

13. Gernetsky, K. (2012, June 18). Teachers get boost to upgrade science, mathematics skills. Business Day, p. 4.

14. Geser, G. (Ed). (2007). Open Educational Practices and Resources OLCOS Roadmap 2012. Salzburg, Austria: Salzburg Research Edumedia Research Group. Retrieved from www.olcos.org/cms/upload/docs/olcos_roadmap.pdf.

15. Hodgkinson-Williams, C. (2010). Benefits and Challenges of OER for Higher Education Institutions. Presented at the Open Educational Resources (OER) Workshop for Heads of Commonwealth Universities, 
Cape Town, South Africa. Retrieved from http://www.col.org/SiteCollectionDocuments/OER_BenefitsChallenges_presentation.pdf.

16. Hoosen, S. (2009). Communities of Practice. Discussion paper, Nairobi, Kenya. Retrieved from http://www.oerafrica.org/resource/oer-africa-communities-practice.

17. Jones, M. (2012, October 12). Education a game of chance. The Mercury, p. 1.

18. Kanwar, A., Kodhandaraman, B., \& Umar, A. (2010). Toward Sustainable Open Education Resources: A Perspective From the Global South. The Amer. Jrnl. of Distance Education, 24, 65-80.

19. Macfarlane, D. (2013, August 13). Damning CHE report into university performance. Mail and Guardian. Retrieved from http://mg.co.za/print/2013-08-20-damning-che-report-into-university-performance.

20. Macfarlane, D., \& Chaykowski, K. (2011, July 15). Bunking teachers fail learners. Mail and Guardian, p. 13.

21. Masondo, S. (2014, January 19). Poor quality drives dropouts. City Press, p. 13.

22. McKay, R. F. (2007). Distributed Communities of Practice: An Exploration of a Distributed Community of Practice of South African Life Science Teachers (Masters dissertation). University of Pretoria, Pretoria. Retrieved from http://www.google.com/url?sa=t\&rct=j\&q=\&esrc=s\&source=web\&cd=1\&ved=0CCgQFjAA\&url=http\%3 A\%2F\%2Fupetd.up.ac.za\%2Fthesis\%2Favailable\%2Fetd-01132009-

131320\%2Funrestricted\%2Fdissertation.pdf\&ei=eNjwUoioI6m57Ab_0YGgDw\&usg=AFQjCNHvwM8bN ygRRJJcXoGqWDU8yfJ3zg\&sig2=Zio871NA6Wft4tZXN6WwHg\&bvm=bv.60444564,d.ZGU .

23. Mngoma, S. (2011, June 9). Hundreds of teachers in KZN not fit to teach key subjects. The Witness, p. 1.

24. Ngcobo, G. (2013, May 28). KZN has a drastic shortage of teachers. The Witness, p. 4.

25. Ngcobo, G., \& Biyela, L. (2012, December 4). KZN's big maths crisis. The Witness, p. 1.

26. Ntsaluba, G., \& Rademeyer, J. (2011, January 26). Maths FAIL! Weekend Witness, p. 4.

27. Pauw, J., Domisse, J., \& Van der Merwe, J. (2012, January 28). Real matric results shock. Weekend Witness, p. 3 .

28. $\quad$ Saunderson-Meyer, W. (2011). Another brilliant ANC idea. Weekend Witness, p. 12.

29. Taylor, N. (2008). What's Wrong with South African Schools? (pp. 1-30). Presented at the What's Working in School Development?, Johannesburg: Jet Education Services. Retrieved from http://www.google.com/url?sa=t\&rct=j\&q=\&esrc=s\&source=web\&cd=3\&ved=0CDIQFjAC\&url=http $\% 3$ A $\% 2 F \% 2$ Fjet.org.za\%2Fevents\%2Fconferences\%2FWhat $\% 2520$ works $\% 2520$ in $\% 2520$ school $\% 2520$ develo pment\%2FPapers\%2FTaylor\%2520Whats\%2520wrong\%2520with\%2520SA\%2520schools\%2520JET\% 25 20Schools\%2520Conf\%2520final.pdf\&ei=4s_oUrHFJNCVhQel_ICABA\&usg=AFQjCNEYpgg582k2DoOXf1cDefjxPmxAA\&sig2=eqO5ZNQllccqpRzZP-BVEA\&bvm=bv.60157871,d.ZG4.

30. Van der Berg, S., Taylor, S., Gustaffson, M., Spaull, N., \& Armstrong, P. (2011). Improving Education Quality in South Africa (pp. 1-26). 2011.09: National Planning Commission. Retrieved from http://www.google.com/url?sa=t\&rct=j\&q=\&esrc=s\&source=web\&cd=6\&ved=0CEsQFjAF\&url=http\%3A $\% 2 \mathrm{~F} \% 2 \mathrm{Fresep}$.sun.ac.za\%2Fwp-content $\% 2$ Fuploads $\% 2 \mathrm{~F} 2012 \% 2 \mathrm{~F} 10 \% 2 \mathrm{~F} 2011$-Report-forNPC.pdf\&ei=p8zoUsfLDoGShQePo4DIBg\&usg=AFQjCNHjP4COYeGRj92b4q3PzQBVC4QJOw\&sig2= e0kJ3EBKbCi50MCwQSSpVA\&bvm=bv.60157871,d.ZG4.

31. Yuan, L., Macneill, S., \& Kraan, W. (2008). Open educational resources-Opportunities and challenges for higher education. Discussion paper. Retrieved from http://wiki.cetis.ac.uk/images/6/6d/OER_Briefing_Paper_CETIS_without_recommendations_with_cover_p age_pdf. 
NOTES 